Jakub Zamana ${ }^{1}$, Janusz Jartyś ${ }^{2}$

\title{
CRITICAL PARADIGM OF THE NAZI LEGACY IN THE FEDERAL REPUBLIC OF GERMANY
}

Keywords: criticism, social engineering, Nazism, Federal Republic of Germany

\begin{abstract}
The objective of this article is to present a critical analysis of selected elements of Nazi legacy in the Federal Republic of Germany (Deutsche Bundesrepublik, BRD). The remnants of the Nazi system have been tolerated, and even sheltered by the authorities of West Germany in almost all aspects of life. A question arises, then, about the effectiveness of the denazification after the Second World War and about a change in mentality in German society, as it should be noted that some elements of Nazi legacy were abandoned only in the 21st century, and therefore the Federal Republic of Germany has not managed to fully make reparations to the victims of Nazism. This article also discusses the fact that in a post-totalitarian state it is extremely difficult to find 'pristine' biographies, considering the number of former members of NSDAP who filled important offices in the BRD.
\end{abstract}

\section{INTRODUCTION}

On the international arena, the Federal Republic of Germany (BRD) seems to be a strong state both in terms of politics and economy, one which has been a co-creator of European integration and is respectful of all citizen rights. One might get an impression, then, that the German state has cut itself off its Nazi past in a political, social and legal sense many

1 Jakub Zamana, University of Warsaw, Faculty of Political Science and International Studies, zamana85@wp.pl.

2 Janusz Jartyś, University of Szczecin, Faculty of Humanities, Institute of Political Science and European Studies, janujar.eu@gmail.com. 
years ago, and that all the sins of the Nazi times were long atoned for and the victims of the system were rehabilitated. The reality is, however, very different. For decades, the Federal Republic of Germany has struggled with its Nazi past in social mentality and in the political and legal system, and even now few aspects of this past have been settled. To refer to a concept created by Thomas Kuhn in 1962, the authors of this article will present a critical paradigm of the Nazi legacy which took roots in the political and legal system of the state and in the minds of its citizens throughout the span of the existence of the Federal Republic of Germany, irrespective of the territorial changes that took place on 3 October 1990 due to the inclusion of the former German Democratic Republic (Deutsche Demokratische Republik, DDR) (Vertrag). In this analysis, the authors implement the genetic method in reference to a case study of Albert Speer, who has been presented for years as an example of "a good Nazi". This article also uses elements of the theory of restoration to illustrate how a part of the Third Reich elite was restored to political life of the BRD, particularly in reference to the ministry of justice and the ministry of foreign affairs. However, the authors to do not analyse the programme and activity of German political parties which openly praise some aspects of the Third Reich era. This problem demands a separate analysis and is only briefly mentioned in this text.

\section{LEGAL ASPECTS AND THE NAZI PAST}

Legal and state continuity of the Third Reich has been evident from the very beginning of the existence of the BRD due to lack of recognition of the German borders after 1945. The presence of the so-called "German East" has been noticeable in the social fabric of the Federal Republic of Germany till today. This issue for years has been linked to a doctrinal conviction about temporariness of the border on the Oder and the Lusatian Neisse rivers, and, by extension, a concept of returning to the borders of the German Reich established on 32 December 1937. Therefore, on the basis of appropriate regulations, for years on the West German maps the latter border was indicated, and the lands intercepted by Poland were 
labelled with the following: "Zu zeitiger unter polnischen Verwaltung", which emphasized the provisional nature of Polish administration in this area. It was also a rule to use German names of now Polish cities, such as Stettin (Szczecin), Breslau (Wrocław) or Allenstein (Olsztyn). According to the regulations issued by the League of German Cities on 13 December 1953, each West German city was supposed to have at least one important street or landmark named after the Eastern territories of the German Reich (Rydel, 2011, p.161). As it turned out, not all such initiatives were successful. According to the regulations issued by the Federal Ministry of Transport, former German cities were to be referred to in the names of the parking lots on highways. As a result, there still is a parking lot in Glesenkirchen called "Rastplatz mit WC Anlage Allensteien", which means "Parking lot with Toilets Olsztyn" (Rydel, 2011, p.163). To stress the importance of the "German East", regulations concerning education were also issued. In 1956, the Conference of Ministers of Culture, which was the main body coordinating education policies in all member lands in the $\mathrm{BRD}$, issued a regulation which demanded that knowledge concerning the "German East" should be included in the handbooks of history and geography and in the professional education of teachers. This regulation was created due to the Federal Community for the Knowledge of the German East in Education, which was established in 1953 (Rydel, 2011, p.163).

The Nazi legacy may be also found in the community of the so-called "Heimatvertriebene" (homeland expellees) - those German citizens who in 1945 had to leave the former German Reich territories as these lands had been annexed to the victorious Poland and the Soviet Union. The myth of the German Reich border from 31 December 1937 has been and still is very strong in the Federal Republic of Germany. This is evident in the article 116 of the Basic Law for the Federal Republic of Germany, which states the following: "Unless otherwise provided by a law, a German within the meaning of this Basic Law is a person who possesses German citizenship or who has been admitted to the territory of the German Reich within the boundaries of 31 December 1937 as a refugee or expellee of German ethnic origin or as the spouse or descendant of such person" (Deutscher Bundestag, 2014, p.114). One should bear in mind that the 
issue of the eastern territories lost by the Germans is till now very alive in the political and social discourse, and was undoubtedly crucial in the first decades of the existence of the BRD. The League of Expellees and Deprived of Rights (BHE) was established in 1950 and led by a former member of NSDAP and SS from Greater Poland, Waldermar Kraft. His party, BHE, gained support of $24 \%$ of votes in Landtag elections in Schleswig-Holstein, and in Bundestag elections in 1853 it got $5.9 \%$ of votes, becoming a member of the government coalition and receiving two ministerial offices. Kraft's party collapsed in 1961 due to a schism in the community of expellees, which took place in 1956. Then, on 27 October 1957 a new organization was established; it included almost all former associations of expellees and formed them into a new one, called the Federation of Expellees (Bund der Vertriebenen, BdV). Throughout the years 1959-1963, the head of the federation was Hans Krüger from CDU, who later took the office of the Minister for Expellees. This Christian Democrat had previously taken part in the Munich Putsch in 1923, and was a longtime member of NSDAP, as well as a judge of special courts, responsible for death sentencing (Rydel, 2011, p.151).

The Federal Republic of Germany has inherited the German Reich legacy and in many cases it has not been attempting to modify it for many years, both in the international and in internal affairs. For instance, the concordat signed between the Holy See and the Third Reich on 20 July 1933 is still valid (Volk, 1972). The Federal Republic of Germany also accepted the German Nationality Law of the German Reich, established in 1913, and then valid during the Weimer Republic and the Third Reich. This law was amended only in 1999. Similarly, the Federal Republic of Germany accepted the Criminal Law of 1871 with all its restrictions introduced during the Third Reich (Daszkiewicz, 1972, p.13). The example of Paragraph 175 concerning indecent behaviour, including homosexuality, clearly demonstrates that the Federal Republic of Germany has been following the strict Nazi law in this respect for many years, penalizing its own citizens on its basis. This regulation was made stricter in 1935, when to its provisions a clause a) was added, which stated that even a suspicion of 
immoral behaviour, such as sexual contacts between men, was enough to charge (Geschichte...). This law was valid in the Federal Republic of Germany in an unchanged form until 1969, and all its remnants were removed from the Criminal Code in 1994 (Jartyś, 2015, p.184). In this time period, on the basis of the provisions of this law 68,000 people were sentenced, including over 60,000 sentences before 1969 (Hoffschidt, 2016, p.27). The Federal Republic of Germany introducing the civil partnership and same-sex marriage acts into its legislation is obviously trying to obliterate those years after 1949 in which Paragraph 175 was in effect. It is, however, an undisputable fact that this state, which is publicly perceived as a democratic one and a cofounder of the European Union, in the first twenty years of its existence has been using an unamended, Nazi version of legal provisions concerning human rights, and prosecuted its citizens based such a law. Even though currently the Federal Republic of Germany constitutes a model state in which the rights and freedoms of citizens, including the non-heterosexual ones, are respected, it has not fully atoned for its past in this respect. The question of moral rehabilitation of people sentenced in the past for homosexual acts on the basis of Paragraph 175 remains open. On 8 May 1985 the President of the BRD Richard von Weizsäker spoke about the suffering inflicted on homosexuals by the Nazis (Sigmund, 2015, p.182). His speech was part of the atonement on behalf of the West German state for the Nazi past. In accordance with the politics of memory, Richard von Weizsäker put his focus on the Holocaust, in this way defining the main victim of the Nazi regime. He spoke on behalf of a generation of perpetrators, reckoning himself and his own family. In his youth, as a captain in Wehrmacht, he entered Poland, and his father held the office of the Minister of Foreign Affairs in the government of the Third Reich. The future president of the BRD defended his father in the so-called Wilhelmstraße Trial, which took place between January 1948 and mid-April 1949. In the end, Ernst von Weizsäker was sentenced to seven years imprisonment, which was later shortened to five years. As a result, he was released in 1950. It has to be admitted that Willy Brandt kneeling in front of the Ghetto Heroes Monu- 
ment in Warsaw on 7 December 1970 was an act which was also a part of the German politics of memory, as much as Richard von Weizsäker's speech on 8 May 1985, although the difference in the biographies of these politicians is enormous. The social democrat Willy Brandt, the mayor of West Berlin and later Chancellor of the BRD, could not be accused of service in Wehrmacht or any kind of connection to the Nazi regime. Willy Brandt had left Germany in 1933, emigrating to Norway, where he engaged in resistance against Nazi authorities. Nazi German authorities strip him of German citizenship. During the years 1937-1939 he was a corresponded of several left-wing newspapers in republican Spain. Once Norway became occupied by Nazi Germany, Willy Brandt emigrated to Sweden, where he continued his anti-Nazi work. This is when Norwegian embassy-in-exile awarded him Norwegian citizenship. In the face of these events, a description made by one of the journalists of "The Spiegel", Hermann Schreiber, when commenting on Brandt's gesture in Warsaw on 7 December 1970, seems particularly apt: "Here is the one who did not have to kneel, yet he did; he kneeled on behalf of those who should have kneeled, but they will not, either because they cannot, or because they have no courage. The blame is confessed by the one who is not to blame, and forgiveness is asked by the one who does not need forgiveness" (Rydel, 2011, p.183).

When it comes to Paragraph 175, one has to mention that it took many years to fully rehabilitate the homosexual victims of Nazi authorities, as it took place in 2002 (Berlin Yogyakarta, 2009, p.7). However, there remains the issue of those people who were prosecuted and sentenced according to Paragraph 175 after 1949. Until now, the Bundestag has only expressed their regrets, while the Bundesrat called to introduce laws which would invalidate the sentences made according to Paragraph 175 (Burgi, Wolff, 2016, p.53). The government of the Federal Republic of Germany started drafting such a law in 2016. As Minister of Justice, Heiko Maasa, assured the public, this law would allow an individual right to compensation and an easy procedure to receive one. The amount of compensation would be established individually, on the basis of, among other things, the length of the prison term that homosexual persons sentenced on the basis of Paragraph 175 had to serve (Niemieccy geje...). German authorities 
plan to assign at least 30 million Euro for compensation to about five thousand gay men still alive in Germany who had been persecuted after the Second World War (Niemcy wypłacą...). There is a chance, then, that the Federal Republic of Germany will atone, at least symbolically, for using a Nazi legislation against homosexual men in ways which were in opposition to the European standards of human rights.

Legal treatment of deserters, oppositionists of the Third Reich and so-called war traitors has also been problematic for the Federal Republic of Germany for many years. It did, however, support financially the spouses of war criminals. A good example of such a case is Marion Freisler, wife of Roland Freiser who led the People's Court (Volksgerichtshof) during the Third Reich and who was responsible for sentencing political dissidents to death for most trivial misdemeanours, such as telling a political joke, listening to a foreign radio station, or sharing food with a forced worker. Roland Freiser ended his life during the bombing in February 1945. After the war, his widow received a generous pension due to the high political position of her deceased husband. However, in 1973 she applied to the Office of Social Affairs for a bonus in war reparations. In her application, Marion Freiser claimed that if it was not for her husband's death, he would have been a popular lawyer or a state official. In a decision made by the Bavarian Minister for Social Affairs Fritz Pirkl from CSU on 5 April 1973, the bonus was awarded to Mrs Freiser on the basis of the War Reparations Act. He justified his decision by claiming that all actions undertaken by Roland Freisler during the war would have been pardoned and he could have continued his career in the Federal Republic of Germany. Therefore, Marion Freisler received the bonus not as a widow of a war criminal, but of a "leading lawyer" who never got a chance to make a career in a democratic state (Fikus, 2013, pp. 232-233). One must also mention that the sentences of the People's Court have been altogether nullified only in 1985. The deserters from Wehrmacht were rehabilitated only in 2002. It follows that for years the Federal Republic of Germany took more care of the inheritors of the Nazi system than of its opposition before it started to face its painful and difficult past (Wahl, 2009, p. 115). 


\section{NAZI LEGACY IN THE STATE APPARATUS AND SOCIAL LIFE OF THE BRD}

Formally, the Federal Republic of Germany has undergone the process of denazification and democratisation, as the defeated German state was obligated to do after the Second World War by the victorious Allied forces. However, the archives of the National Socialist German Workers' Party (NSDAP) opened in 1994 show that denazification of West Germany was superficial. The research done in the archives by a German journalist and scholar Malte Herwig demonstrates that until 1990s among the leading politicians in the BRD there were more than twenty-five members of CDU, CSU, FDP and even SPD who were in NSDAP during Nazi dictatorship. Among them one may find the Federal Chancellor Kurt Georg Kiesinger, the Federal President Walter Scheel and 25 ministers, including Hans Dietrich Genscher, who for many years was the Vice-Chancellor and Minister of Foreign Affairs in the BRD government. Admittedly, his further contribution to Polish-German reconciliation and European integration, which won him the Honorary Doctorate of Szczecin University in 2002 cannot be denied (Doktorzy Honoris...), yet he denied being a member of NSDAP of his own volition, as many representatives of his generation did. In an interview for "Stern" magazine he said: "I did not sign any application form" (Herwig). However, the aforementioned researcher of NSDAP archives decidedly rejects explanations given by the leader of German diplomacy, claiming: "It is impossible that he did not know about it. There is his signature on the application form. It is hard to imagined that he was forcefully engaged in NSDAP. During the war dictators are looking for active members, who could create propaganda on their behalf, they are not interested in fake memberships" (Jak RFN...). In spite of Hans Dietrich Genscher's assertion, one may find his party identity card numbered 10123636, issued in his name (Herwig). This is not just a single instance of shameful NSDAP membership. For many years other representative of political and cultural life of the BRD have been hiding their involvement in Adolf Hitler's party. Among them are respected representatives of SPD, such as Prof. Horst Ehmke and Erhard Eppler, as well as composer Hans Werner Henze, literary historian Walter Jens, writers 
Siegfried Lenz, Erich Lőst and Dieter Weller Hoff, philosopher Hermann Lübbe, and world-renown sociologist Niklas Luhmann. Finally, among the aforementioned Germans with a Nazi past is also the laureate of the Nobel Prize for Literature, Günter Grass, who served in Waffen SS during the Second World War (Łepkowski).

The aforementioned representative of political and cultural life in the BRD are not the only people on the list of superficial denazification in the Federal Republic of Germany after the Second World War. Still in 1960s, $60 \%$ of leading positions in the legal system of West Germany were held by former members of NSDAP. In 1970s, among the employees of the West German Ministry of Justice, every fifth of them had a past with SA; a similar ratio was among the leading positions in the ministry. 93 directors and managers in the ministry had a Nazi past, and 27 of them worked in the ministry during the Third Reich era. Taking into account, that the total number of such positions in the ministry at the time was 170, one may conclude that it was the most Nazi-oriented ministry in the government of the Federal Republic of Germany (Wieliński). It was, therefore, paradoxical that people accused of war crimes were judged by former members of the Nazi party. This is backed up by particular instances of employees of the aforementioned ministry. For example, the former Attorney General of the BRD Wolfgang Fränkel during the Nazi rule 30 times forwarded a motion of capital punishment for most insignificant misdemeanours, such as bike or food theft. In 1942 he sentenced to death a thief who stole a female handbag. Even when the president of the People's Court himself suggested that he should offer a more lenient punishment due to minimal social danger of the act and low mental capabilities of the perpetrator, Wolfgang Fränkel did not agree to change his mind. However, the Bundestag committee reviewing this case after the Second World War did not assess the behaviour of the prosecutor nor the judge to be erroneous (Naziści robili...).

In the light of the aforementioned number of former Nazis in the West German administration of justice it is not surprising that the way the Third Reich was perceived in the Federal Republic of Germany was influenced by the opinions of the president of the Federal Court of Justice Hermann Weinkauff. During the Third Reich he was an assistant judge of 
the Reich Supreme Court and in 1937 he was promoted to the position of the associate judge of the Supreme Court. In the Federal Republic of Germany he became an avid supporter of rehabilitating the war criminals to public life. He was particularly engaged in the cases of those judges who were accused because of their work during the Nazi era. He was also against any rehabilitation of dissidents against the Nazi state (Fikus, 2013, pp. 58-59).

A situation similar to that in the judiciary system also took place in the Ministry of Foreign Affairs in the BRD, as among their employees 30\% were former NSDAP members. Restoration of part of the Third Reich elite was enabled by article 131 of The Basic Law for the Federal Republic of Germany, included in the Transitional and Concluding Provisions, titled "Persons formerly in the public service" (Deutscher Bundestag, p.121). These provisions allowed to restore former members of NSDAP, or even SS or Gestapo, to civil service. In consequence, they paralyzed the attempts to pursue Nazi criminals (Fikus, 2013, p. 44).

In 1950s and 1960s the authorities of the Federal Republic of Germany were not interested in a thorough denazification of the state. This attitude was shared by Chancellor Konrad Adenauer, who said: "if we keep looking, there is no way of knowing who we will end up with" (Kokot, Jak RFN...). It must be remembered, however, that in his immediate circle there were people with a Nazi past. Among them was an éminence grise in Konrad Adenauer's government, Hans Globke - the co-creator of the Nuremberg Laws - who held a position of the Secretary of the State, and Theodor Oberländer, the leader of Intelligence Services and an ex-general in Wehrmacht (Tomczak). In the first government created by Adenauer the Minister of Transport was Hans-Christoph Seebohm, who in the Third Reich era was decorated with the highest Nazi honour, Blutorden. In 1951 he said: "I will always honour any symbol of our nation - I say it loud and clear: any symbol - in the name of which the Germans gave their life for their country" (Wahl, 2009, p.133). For those who listened to him there was no doubt that the symbol he mentioned was a swastika. According to data collected by Hannelore Gerstein and Hartmut Schellhoss, 20\% of people in the second government led by Konrad Adenauer had NSDAP past (Wahl, 2009, p. 133). 
The Nazi legacy may be also found in the sport in the Federal Republic of Germany. Peco Bauwens, the president of the Deutscher Fußball-Bund (DFB) from 8 July 1949, during the Nazi era was at the forefront of Fachamt Fußball and a member of the International Executive of FIFA. He obviously believed that Germany will win the war. After the Third Reich collapsed, he claimed that the Nazi drove his non-Aryan wife to suicide. In reality, the motivations for this act were personal (Wahl, 2009, pp.241-242). When in 1954 the BRD football representation won the World Cup, Peco Bawens said on 6 July 1954 in a pub: "We lost two wars, but this time we won" (Wahl, 2009, p.246). He also used Nazi exclamations, such as „better Deutschetum abroad” or "attacking the opponent with a German flag in heart, from a Nazi losgestürmt". A similar attitude was shared by a large part of the West German society. According to Dutch correspondents, the Germans treated wining the World Cup as retribution for 1945 (Wahl, 2009, p.246). In pubs, "Horst Wessel-Lied" was sung euphorically. There were incidents reported, for instance a case of a brawl, in which a man who noted to a group of Germans that they are singing the first stanza of Deutschalandlied, staring from "Deutschland, Deutschland über alles" and not the third which is the official anthem of the BRD from 1952, was beaten up (Wahl, 2009, p.245).

Another Nazi activist who returned to the world of sport in the Federal Republic of Germany is Carl Diem, who in 1950 was appointed by the Chancellor Konrad Adenauer to be the government advisor for the affairs of sport and the youth. He later joined CDU, and in 1953 was decorated with the highest honour, the Order of Merit of the Federal Republic of Germany (Wahl, 2009, p. 250). During the Third Reich era Carl Diem was a member of the general secretary for the Olympic Games in Berlin. In 1938 he was appointed by Wilhelm Fick to be the director of the International Olympic Institute, and then the director of the Foreign Affairs Department. In years 1939-1942 he gave over a hundred lectures for the soldiers of Wehrmacht, where he praised the values of sport in the Nazi service (Wahl, 2009, p. 248). The issue of Carl Diem's past returned when in 1972 an idea was suggested to name one of the Olympic Village streets in Munich after him. This proposal resulted in an international protest, which surprised young German sportspersons who did not know Diem's 
real biography. In the Federal Republic of Germany in 1954-55, when he reminisced on the manifestation of gymnasts with Adolf Hitler in Stuttgart, Carl Diem said: "Hitler gave a good speech (...). His speech was welcomed with ovation" (Wahl, 2009, p.251). Talking about one of the Reichsporttஐhrers, he said: "He made some great contribution to German sport" (Wahl, 2009, p.251). Diem also praised Hitlerjugend for "a good job" and SS for their "purely sport-oriented activities". What is more, Carl Diem used to call the Nazi system a "typical authoritarian regime" and since 1955 he eagerly used the title "der F囚hrer". There is little wonder, then, that he would mention an SS doctor as a "world-renown physician", and even in Carl Diem's own funeral references were made to the Third Reich. The funeral guests remembered Diem as "a great humanist", which was a euphemism used for former Nazis in the BRD. On the centenary of his birth in 1982, Carl Diem was called "a father and a teacher of the nation" (Wahl, 2009, pp.250-251).

A similar situation was evident during the creation of the Bundeswehr in the Federal Republic of Germany. Admittedly, the current name of the German army signifies the defence of the republic, yet during its constitution it had more in common with the Third Reich than with a democratic state. The officers enrolled to the Bundeswehr did not understand the rules of a democratic state and civil control over the army. In the BRD during peace the Minister of the Defence has control over the army, while during war it is the Federal Chancellor. During the Cold War the past of the army officers was not delved into. Former officers of Wehrmacht would not understand that in a democratic state a soldier has a right to oppose his superior in the name of the rules of democracy. This standard was often forgotten and the attitude resembled that in the Nazi army. In the light of this situation, SPD was pressured into creating a committee which would verify the candidates to the Bundeswehr. It was run by Otto Rombach, who was the mayor of Aachen until 1933. Until 1957 six hundred personal files of the Bundeswehr candidates were verified. Even in the initial stages of this verification, 51 persons were assessed negatively, and further 41 candidates resigned from applying to serve in the army. The first generals in the West German army have lived through the service in Wehrmacht on the eastern front. According to the rules applied in the Bundeswehr, 
SS officers were not to be accepted. Yet, the committee moderated its initial requirements and allowed former members of SS to apply if their military rank was below colonel. In the end, out of 3117 SS-Waffen officers, 508 persons were accepted into the Bundeswehr, mainly in appreciation of their extremely anti-communist opinions (Wahl, 2009, pp.179-180). This decision met with protests in the BRD and abroad. There is little wonder, then, that in that period of time the authorities of the People's Republic of Poland presented the Bundeswehr as inheritors of Hitler's army in their propaganda (PKF 1960 45b). Even before the creation of the Bundeswehr, a myth of "chivalrous Wehrmacht with clean hands" appeared in the Federal Republic of Germany. The international situation of the time was conductive to creating such a myth. On 22 January 1951 the Chancellor Konrad Adenauer demanded the commander of NATO Dwight D. Eisenhower to declare that the German officers and soldiers did not profane their honour during the war, and then himself in the Bunderstag on 5 April 1951 he assured that "the federal government appreciates all military of our nation, who in the name of the great military tradition fought on land, sea and in the air with honour" (Rydel, 2011, p. 113). Adenauer used a phrase "Waffenträger" in his speech, which it referred to all military, including Waffen-SS. In the context of such politics of the West German government, backed up by the media, many associations for former Wehrmacht soldiers and Waffen-SS were created, and the Bundeswehr named thirty crucial landmarks after the "heroes" of the Second World War (Rydel, 2011, p.113). For instance, in 1964 the barracks of the Mountain Division in Füssen were named "Generaloberst Dietl", after General Eduard Dietl, the "hero of Narvik" and a member of NSDAP, whom Hitler remembered as "the first German officer who understood him and gave himself to his disposal" (Rydel, 2011, p.114). Although in $1982^{\text {th }}$ West German Ministry of Defence banned the Bunderswehr from referring to traditions of Wehrmacht, the name of the aforementioned barracks was used until 1995. The patron of 74 Fighter Squadron, Werner Mölders, was similarly controversial, as the ace of Luftwaffe and a member of the Condor Legion who fought over Guernica during the civil war in Spain. The patron name of this unit was changed as late as 2005, although 
the guided missile destroyer which is a museum ship of the German navy carries Mölders's name till now (Rydel, 2011, pp. 113-114).

The aforementioned examples are part of a process that took place in West Germany at the time, which led to moral relativisation of former membership in NSDAP and of the engagement in Nazi regime. The West German mentality of those days suggested that not every member of NSDAP and not every Nazi was evil and criminal, as not everyone was a criminalist. This mentality is well illustrated by the case of Albert Speer, the main architect of the Third Reich, sentenced by the International Tribunal in Nuremberg for twenty years of imprisonment. During his incarceration in Spandau prison, then West Berlin, he wrote his memoirs, whitewashing himself and minimizing his role in the Nazi state apparatus, both as its architect and later its Minister of Economy and Ordnance (Speer, 1990). This publication, released in 1969, brought him financial profit and became an international bestseller, and its author became an unusual star of the West German media, eagerly giving interviews about the Third Reich. The image of a nice man in his sixties, mainly telling stories about his work as an architect during the rule of Adolf Hitler led to the conviction, common both in the BRD and abroad, that Albert Speer was "a good Nazi" who had nothing to do with Nazi crimes. The truth was, however, very different. According to documents uncovered several years ago, Albert Speer, „the Democrat's favourite Nazi”, as he was sometimes called, was a war criminal. He was responsible not only for the process of deJudaisation of Berlin during the redevelopment of the city, which means relocating and removing Jewish citizens of Berlin to concentration camps, but also for using forced labourers from concentration camps when he was in the ministry office of the Third Reich (Kitchen, 2017). Possibly, if all these facts were known during the Nuremberg Trials, Albert Speer would have been executed. Yet he spared his life, due to judges' lack of knowledge, his own intelligence and luck; Adolf Hitler's main architect lived to be seventy-five, enjoying reputation of a great architect and "a good Nazi." At the same time, the myth of Albert Speer became a part of the politics of memory which relativized the complication of the Third Reich and the people involved in its regime. 
The legend of Albert Speer as a good architect survived a long time in Germany and help the career of his son, who followed in this father's footsteps. Albert Speer Junior, who died on 15 September 2017 at the age of 83 (Spiegel) was one of the most appreciated architects in the Federal Republic of Germany. His architectural office Albert Speer \& Partner in Frankfurt-am-Mein was held in good esteem. Albert Speer was responsible, among other things, for the Expo 2000 exhibition in Hannover and for the extension of the airport in Frankfurt-am-Mein. He also designed Anting New Town (a town for 50,000 employees of the Volkswagen factory near Shanghai) and Changchun district for 300,000 inhabitants. The son of the well-known architect was also a successful academic and became a professor and the Dean at the Technical University in Kaiserslautern. He very rarely mentioned his father. He was, however, sentimental about his childhood spent near the Führer's residence in Berchtesgaden (Kacewicz).

The participation of the former members of NSDAP in the public life of the Federal Republic of Germany also led to somewhat paradoxical situations. For instance, the Treaty of Warsaw of 1970 between the People's Republic of Poland and the Federal Republic of Germany concerning the basis of normalisation of their mutual relations was signed on 7 December 1970 by the social democratic Chancellor Willy Brandt, and by Walter Scheel, who was then the Minister of Foreign Affairs and who used to belong to NSDAP; on behalf of the Polish government, however, it was signed by the Prime Minister of the People's Republic of Poland, Józef Cyrankiewicz, who was a former inmate of a Nazi concentration camp, and by the Minister of Foreign Affairs (Dziennik Ustaw 1-2).

One cannot also forget that questions about the past during the Nazi era arose when a 77-year-old cardinal Joseph Ratzinger was elected to be the Pope of the Catholic Church, and during his pilgrimage to Israel. The Director of the Holy See Press Office issued a statement claiming that Joseph Ratzinger was conscripted in 1943 to the auxiliaries of the anticraft warfare. "It was an auxiliary force, and had nothing to do with the Nazis and the Nazi ideology", the Holy See Press Office stated (Guzik). This claim represents German narration about Wehrmacht and other military formations which operated in the Third Reich. It is possible that 
a sixteen-year-old boy was forcefully conscripted to Wehrmacht; it is, however, highly doubtful that such military formations had nothing to do with the Nazis and Nazi ideology.

The attitude of the former NSDAP members who continued their public life in the democratic state of the Federal Republic of Germany represent the social engineering methods, particularly those of manipulative accreditation and discreditation (Karwat, 2007, pp.190-263; Karwat, 2016, pp.187-331; Zamana, 2017, pp.73-75). One of the basic requirements for participation in German politics after the collapse of the Third Reich in the BRD was, on the one hand, authentication via reference to democratic axiology and, on the other, rejection of any manifestation of authoritarianism or totalitarianism. It was a method based on manipulative self-representation in order to achieve accreditation (authentication). In this case, the German politicians created their image and increased their attractiveness as defenders of freedoms and human rights by a skilful rejection of their own past. This method may be described as "a process of instinctive inferring what the needs of the opponent are, which features may be valuable for them, and then projecting an image of oneself that would fulfil these needs (..)" (Lis-Turlejska, 1980, p. 326). In this case, the projecting subject adjusts itself to its environment and the systemic conditions. In other words, the subject becomes the spokesperson and creator of new reality. Depending on requirements and milieu, they might either be an ally to minorities, or work against them; be a warden of freedom and democracy, and then, at the same time, the main enemy of these values.

Another important factor in the process of accreditation of the subjects participating in the process of transformation is to use social engineering techniques based on discretiation (of ideology, history, of a banner or a group). This technique rests upon the democratic subject, for instance, who used to be on the side of the totalitarian rule, becomes the proponent of a total discreditation of the previous system, its symbols, institutions and people (Karwat, 2007, p.267). That is why so often the main architects of revolutionary or evolutionary changes are surrounded by critics, or even enemies, who in fear of losing their position or of a judgement side with the new political power. As is shown by the history of conditions and 
mechanisms of political and systemic transformations, from totalitarian and authoritatian towards liberal democracy in the $20^{\text {th }}$ century, in European countries many former political officials authenticated new democratic political projects by joining new political parties. The most crucial political mystification took place in those states where the past of the new political elites was purposefully obscured. The experience of the BRD illustrates that continuation of a political career by former activists of NSDAP was possible due to social engineering, and, on the other hand, due to weaknesses of the state or conscious discouragement of all citizen of the new state to take part in a positive cooperation.

Summing up, one of the main factors affecting the success of former NSDAP members in the BRD was skilful exploitation of mechanisms of social engineering, based on accreditation, manipulative self-representation and discreditiation in order to change their identity.

\section{CONCLUSIONS}

After the social and political transformation in Poland in 1989 there has been a spreading conviction among the political and social elite of Poland that the affluent neighbouring state of the Federal Republic of Germany is a fully democratic country, with nothing to do with its Third Reich past. It was claimed then that the anti-German rhetoric of the governments of the People's Republic of Poland, which for four decades had been claiming that the BRD had not fully atoned for its Nazi era, had been only soviet propaganda resulting from political, economic and military dependence of Poland from the Soviet Union. If it is true, it is only partly so. It should be remembered that the politicians of the People's Republic of Poland and their advisors in great majority lived through the occupation of the Third Reich. Moreover, quite probably the intelligence and diplomacy were at least to some extent aware of the results of denazification in the Federal Republic of Germany. Leaving the propaganda and ideology of the times aside, it has to be confirmed that accounts of the deep rooting of Nazi legacy in the BRD were not exaggerated, if the current knowledge of the issue is to be taken into account. 
Even though it has been 72 years since the collapse of the Third Reich, and 68 years since the creation of the Federal Republic of Germany, it must be concluded that this state has not fully disposed of its Nazi past in many aspects of political, social and legal life. As the Federal Republic of Germany has tolerated people and values linked to Nazism for decades, and even incorporating them into the system of their democratic state, the BDR is now in a new kind of trouble. Public opinion in Poland is alarmed by the electoral success of Alternative for Germany (AfD) - an extremely right-wing party - in the Bundestag elections in September 2017, and by a statement made by its leader, Alexander Gauland, who said that the Germans have a right to be proud of their soldiers fighting in both world wars (Lider AfD...). One has to ask, however: was it not the Chancellor Konrad Adenauer who first absolved the Wehrmacht soldiers in his Bundestag speech quoted in this article? Was it not the Chancellor of reunified Germany, Helmut Kohl, who called himself numerously the political inheritor of Konrad Adenauer? Did he also share Adenauer's negative attitude of denazification and agreed to the presence of former Nazis in the entourage of the first Chancellor of the BRD? Was it not CDU which affiliated the Federation of Expellees, which for years has been issuing territorial and financial demands against Poland? After many years, the CDU and the Bavarian CSU reap what was sown by both parties since 1949. This takes form of the electoral success of AfD, as their constituency uses the immigration crisis as an excuse to resurrect old slogans promoted by CDU and CSU. Both these parties became too liberal for AfD electors and too similar to left-wing slogans of SPD or the Green Party. Therefore, the values propagated for years in the Federal Republic of Germany have their comeback.

The fact that the BDR failed to fully settle score with its Nazi past has become an inspiration of a thriller written by a British writer Frederick Forsyth in 1972, titled "The Odessa File." The novel was written with the help of Simon Wiesenthal, a known hunter of Nazi war criminals. It tells a story of a secret agency which helps former members of SS, called "Odessa", a German acronym of "Organisation der Ehemaligen SSAngehorigen". The novel was adapted into a film two years after its publication (Acta ODESSY). In spite of its sensationalism, the novel represents 
a story which taps into German politics of memory, with the father of the main character, a Wehrmacht captain decorated with Iron Cross with oak leaves, being differentiated from the criminals from SS. Irrespectively, the novel presents a large number of Nazi officials in the public institutions of the Federal Republic of Germany in 1963.

This article constitutes a critical analysis of the Nazi legacy in the Federal Republic of Germany and represents only selected examples. The scale of this legacy is, however, enormous, particularly in the first thirty years of the state's existence. It also paints a different picture of Chancellor Konrad Adenauer than the one generally believed. He is not only an elderly politician who had a great contribution in the reconciliation of Germany and France, a creator of a federal idea of unified Europe, but also a person who tolerated former Nazis and references to the system of the Third Reich in the internal affairs of the BRD and in its public life. In this context, the words of Konrad Adenauer's elderly former gardener, spoken during Willy Brand's electoral campaign, gain extra meaning, as he said holding red roses: "Adenauer grew roses, but roses are for Willy Brandt, because he brought peace to the world" (Bundestagwahl, 1972). Of course, one could accuse Willy Brandt that he also tolerated the ViceChancellor and Minister of Foreign Affairs Walter Scheeler, who had a Nazi past. However, information about Scheeler's engagement in NSDAP saw the light only in 1994, after Willy Brandt's death. It is impossible to expect that Walter Scheeler, being a prominent politician of FDP in 1970s, would reveal his shameful past himself. It is indisputable that the left-wing parties such as SPD or the Green Party, with all their faults, played an important part in weeding the Nazi legacy out of the public life in the BRD. They still do, as is evident in the stern criticism of the words spoken by the leader of AfD offered by Thomas Oppermann from SPD. He said:"I cannot imagine how one may be proud, even to the smallest extent, of the millions of victims of barbaric war crimes and destruction brought to whole Europe (...). Gauland turned out to be an ultra-right militarist" (Lider AfD...). 


\section{BIBLIOGRAPHY:}

Acta ODESS. Downloaded from: https://www.youtube.com/watch?v=XIVNVz5TYHo Albert Speer junior. Downloaded from: http://www.spiegel.de/kultur/gesellschaft/albertspeer-junior-deutscher-star-architekt-verstirbt-nach-sturz-im-haus-a-1168124.html. Berlin Yogyakarta, (2009). Od hitlerowskiego terroru wobec osób homoseksualnych do praw człowieka dzisiaj, Warszawa: Kampania Przeciw Homofobii.

Bundestagwahl 1972 SPD Spot. Downloaded from:

https://www.youtube.com/watch?v=DATZtb2q6rY

Burgi, M., Wolff, D. (2016). Rehabilitierung der nach $\$ 175$ StGB verurteilten homosexuellen Männer: Auftrag, Optionen und verfassungsrechtlicher Rahmen, Antidiskriminierungstelle des Bundes, Berlin: Nomos.

Daszkiewicz, K. (1972). Zbrodnie hitlerowskie w prawie karnym Niemieckiej Republiki Federalnej, Poznań: Instytut Zachodni.

Deutscher Bundestag. Basic Law for the Federal Republic of Germany. Trans. Christian Tomuschat. David P. Currie, and Donald P. Kommers. 23 Dec 2014. Web. 03 Dec 2017. Downloaded from: https://www.btg-bestellservice.de/pdf/80201000.pdf

Doktorzy honoris causa. Downloaded from: http://www.usz.edu.pl

Dziennik Ustaw Polskiej Rzeczypospolitej Ludowej nr 24, Warszawa dnia 20 czerwca 1972.

Fikus, S. (2013). Trudny spadek dysydentów III Rzeszy w Republice Federalnej Niemiec, Warszawa: Instytut Historii PAN.

Geschichte Projekte. Downloaded from: https://www.unioldenburg.de/fileadmin/user_ upload/geschichte/projekte/ol.verfolgungsszenarien/download/Rosa_Winkel-script. pdf

Grudgesetz für die Bundesrüepublik Deutschland. (2004). Berlin: Bundeszentrale für politische Bildung.

Guzik, J. Rzecznik Watykanu: Papież nie był nigdy w Hitlerjugend. Downloaded from: http://www.rp.pl/artykul/304327-Rzecznik-Watykanu--Papiez-nie-byl-nigdy-wHitlerjugend.html

Herwig, M. Und die Größe ist gefährlich, und der Ruhm ein leeres Spiel. Downloaded from: http://www.stern.de/politik/deutschland/hans-dietrich-genscher-und-das-heiklekapitel-seiner-nsdap-mitgliedschaft-6775028.html.

Hoffschildt, R. (2016). Kriminalisierung und Verfolgung homosexueller Handlungen unter Männern durch Justiz und Polizei in der Bundesrepublik Deutschland von der Nachkriegszeit bis 1994, Hannover.

Jartyś, J. (2015), Wkład Polski do procesu umiędzynarodowienia praw osób Lesbian, Gay, Bisexual, Transgender (LGBT) po akcesji Polski do Unii Europejskiej. In: L. 
Wojnicz, D. Rdzanek, M. Potkańska (eds.). W poszukiwaniu finalite politique Unii Europejskiej. Aspekty teoretyczne i praktyczne (pp. 183-197). Szczecin - Warszawa: Instytut Politologii I Europeistyki Uniwersytetu Szczecińskiego, Instytut Europeistyki Uniwersytetu Warszawskiego.

Kitchen, M. (2017). Speer. Architekt śmierci, Warszawa: Wydawnictwo Prószyński i Spółka.

Kacewicz, M. Nosze nazwisko potwora. Downloaded from: http://www.newsweek.pl/ swiat/nosze-nazwisko-potwora,65994,1,1.html.

Karwat, M. (2007). O złośliwej dyskredytacji - manipulowanie wizerunkiem przeciwnika, Warszawa: Wydawnictwo Naukowe PWN.

Karwat, M. (2009). Akredytacja w życiu społecznym i politycznym, Warszawa: Oficyna Wydawnicza ASPRA-JR.

Kokot, M. Jak RFN przez długie lata krył nazistów w swoich rządach. Nowa ksiązka badacza Downloaded from:

http://wyborcza.pl/1,76842,13867398,Jak_RFN_przez_dlugie_lata_kryl_nazistow_w_ swoich_rzadach_html .

Lider AfD dumny z żolnierzy Wehrmachtu. Downloaded from: http://www.dw.com/pl/ lider-afd-dumny-z-\%C5\%BCo\%C5\%82nierzy-wehrmachtu/a-40530087

Lis-Turlejska, M. (1975). Ingracjacja, czyli manipulowanie innymi ludźmi za pomocą zwiększenia własnej atrakcyjności. In: J. Reykowski (ed.), Osobowość a społeczne zachowanie się ludzi (pp. 29-37). Warszawa: Wydawnictwo KiW.

Łepkowski, P. Rzecz o historii. Jak naziści zbudowali współczesne Niemcy. Downloaded from: http://www.rp.pl/Rzecz-o-historii/309019905-Jak-nazisci-zbudowali-wspolczesne-Niemcy.html.

Naziści robili kariery w resorcie sprawiedliwości RFN. Downloaded from: http://www. newsweek.pl/swiat/nazisci-robili-kariery-w-resorcie-sprawiedliwosci-rfn,105220,1,1. html

Niemieccy geje z odszkodowaniami za prześladowanie. Downloaded from: https://parezja. $\mathrm{pl} /$ niemieccy-geje-odszkodowaniami-przesladowanie/

Polska Kronika Filmowa (PKF 160 45b). Downloaded from:

https://www.youtube.com/watch?v=0V5kz65Bb3g (7 X 2017)

Rydel, J. (2011). Polityka historyczna Republiki Federalnej Niemiec. Zaszłości, idee, praktyka, Kraków: Wydawnictwo Uniwersytetu Pedagogicznego.

Sigmund, A.M. (2015). Sex w III Rzeszy, Warszawa: Bellona.

Speer, A. (1990). Wspomnienia, Warszawa: Wydawnictwo Ministerstwa Obrony Narodowej.

Tomczak, S. Rok 1968 w Republice Federalnej Niemiec i jego skutki. Downloaded from: https://historia.org.pl/2013/08/10/rok-1968-w-republice-federalnej-niemiec-i-jegoskutki/. 
Vertrag zwischen der Bundesrepublik Deutschland und der Deutschen Demokratischen Republik über die Herstellung der Einheit Deutschlands (Einigungsvertrag), https:// www.gesetze-im-internet.de/einigvtr/EinigVtr.pdf (7 X 2017)

Volk, L. (1972). Das Reich Konkordat vom 20 Juli 1933. Von den Ansätzen in der Weimarer Republik bis zu Ratifizierung am 10 September 1933, Veröffentlichungen der Komission für Zeitgeschichte bei der Katholischen Akademie in Bayern, Mainz: Matthias-Grünewald Verlag.

Wahl, A. (2009). Druga historia nazizmu w federalnych Niemczech po 1945 roku, Warszawa: Wydawnictwo Akademickie Dialog.

Wieliński, B.T. Naziści w niemieckim ministerstwie sprawiedliwości. Rozliczanie brunatnego resortu. Downloaded from: http://wyborcza.pl/1,75399,20834124,nazisci-wniemieckim-ministerstwie-sprawiedliwosci-rozliczanie.html.

Zamana, J.(2017). Pojęcie socjotechniki. Dialog Edukacyjny, 1-2. 